\title{
Genetic Comparison of Stemness of Human Umbilical Cord and Dental Pulp
}

\author{
Chung-Min Kang, ${ }^{1}$ Hyunok Kim, ${ }^{1}$ Je Seon Song, ${ }^{1}$ Byung-Jai Choi, ${ }^{1}$ Seong-Oh Kim, ${ }^{1}$ \\ Han-Sung Jung, ${ }^{2}$ Seok-Jun Moon, ${ }^{3}$ and Hyung-Jun Choi ${ }^{1}$ \\ ${ }^{1}$ Department of Pediatric Dentistry, College of Dentistry, Yonsei University, Seoul, Republic of Korea \\ ${ }^{2}$ Department of Oral Biology, Division of Histology, College of Dentistry, Yonsei University, Seoul, Republic of Korea \\ ${ }^{3}$ Department of Oral Biology, Division of Pharmacology, College of Dentistry, Yonsei University, Seoul, Republic of Korea \\ Correspondence should be addressed to Hyung-Jun Choi; choihj88@yuhs.ac
}

Received 9 February 2016; Accepted 3 March 2016

Academic Editor: Boon C. Heng

Copyright (C) 2016 Chung-Min Kang et al. This is an open access article distributed under the Creative Commons Attribution License, which permits unrestricted use, distribution, and reproduction in any medium, provided the original work is properly cited.

\begin{abstract}
This study focuses on gene expression patterns and functions in human umbilical cord (UC) and dental pulp (DP) containing mesenchymal stem cells (MSCs). DP tissues were collected from 25 permanent premolars. UC tissue samples were obtained from three newborns. Comparative gene profiles were obtained using cDNA microarray analysis and the expression of tooth development-associated and MSC-related genes was assessed by the quantitative real-time reverse transcription polymerase chain reaction (qRT-PCR). Genes related to cell proliferation, angiogenesis, and immune responses were expressed at higher levels in UC, whereas genes related to growth factor and receptor activity and signal transduction were more highly expressed in DP. Although UC and DP tissues exhibited similar expression of surface markers for MSCs, UC showed higher expression of CD29, CD34, CD44, CD73, CD105, CD146, and CD166. qRT-PCR analysis showed that CD146, CD166, and MYC were expressed 18.3, 8.24, and 1.63 times more highly in UC, whereas the expression of CD34 was 2.15 times higher in DP. Immunohistochemical staining revealed significant differences in the expression of genes (DSPP, DMP1, and CALB1) related to odontogenesis and angiogenesis in DP. DP and UC tissue showed similar gene expression, with the usual MSC markers, while they clearly diverged in their differentiation capacity.
\end{abstract}

\section{Introduction}

Mesenchymal stem cells (MSCs) have attracted a great deal of interest because of their potential application in regenerative medicine and tissue engineering. MSCs are highly proliferative and adherent fibrotic cells that express characteristic cell surface markers and retain self-renewing capacity with the potential of differentiating into various tissues including bone, muscle, cartilage, fat, and nerve [1]. MSCs may be isolated readily from several tissues such as bone marrow, adipose tissue, and placenta [2]. Although MSCs derived from bone marrow are well characterized, the harvest of stem cells from the bone marrow is a highly invasive procedure with a considerable risk of donor site morbidity.

Recently, potential alternative sources of MSCs and nonaggressive methods for the harvesting of stem cells have been investigated; in particular, the umbilical cord (UC) and dental pulp (DP) show great promise as source tissues because they contain a considerable number of cells with properties similar to those of MSCs [3, 4]. In recent years, UCMSCs have shown an odontogenic differentiation potential to differentiate into odontoblast-like cells in an odontogenic microenvironment [5].

UC tissue (Wharton's jelly of human umbilical cord) is considered an ideal source of stem cells with characteristics similar to those of MSCs from bone marrow and adipose tissue, for example, fibroblast morphology, surface protein markers, and potential for differentiation into cells of therapeutic value [6, 7]. UC cells exhibit immunosuppressive capacity and high proliferation rates, which are useful in allogeneic environments $[8,9]$. DP, which is thought to be derived from migratory neural crest cells during development, is 
a source of various populations of multipotent stem cells [10]. Similar to MSCs, dental pulp stem cells (DPSCs) are adherent clonogenic cells with varying capacities for differentiation along mesenchymal or nonmesenchymal lineages [11].

The UC is a potentially valuable source of MSCs as the isolation process is noninvasive and causes no harm to the mother or infant and utilizes material that is usually discarded [12]. In addition, UC tissue is derived from the neonate and is therefore less mature than adult tissues. This lowers the risk of immune reactions during donor transplantation. DPSCs also represent a valuable source of MSCs, as the latter may be obtained with minimal pain and morbidity [13]. Therefore, MSCs derived from the UC and DP are more desirable for stem cell-based therapy than stem cells obtained from conventional sources such as bone marrow.

Despite extensive knowledge of the properties of UCMSCs and DPSCs, it is still not known whether their properties accurately reflect their true gene expression patterns and developmental potential in situ. The fate of stem cells is regulated by cell-intrinsic determinants and signals within a specialized microenvironment [14]. Therefore, investigation of the genes related to stemness in UC and DP is necessary in order to evaluate the potential value of these tissues as alternative sources of MSCs. In particular, their gene expression patterns must be analyzed to obtain insights into the differentiation capacity of the stem cells and to compare the biological functions of the stemness-related genes in terms of interactions with the microenvironment. In this study, we performed a DNA microarray-based differential gene expression analysis of UC and DP tissues with the aim of comparing the characteristics of MSCs from each type of tissue.

\section{Materials and Methods}

2.1. Tissue Samples. The experimental protocol was approved by the Institutional Review Board of Yonsei University Dental Hospital (\#2-2012-0001) and Severance Hospital (\#4-20120408). All the subjects or their guardians have provided written informed consent. Pulp samples were obtained from healthy permanent premolars $(n=25$; from 5 males and 6 females, aged 11-25 years) extracted for orthodontic reasons. The fresh umbilical cord tissues were obtained from three newborns in the Department of Obstetrics and Gynecology, Severance Hospital, Yonsei University. The extracted teeth and umbilical cords were frozen immediately and stored in liquid nitrogen. The pulp tissue was obtained using sterile tweezers and barbed broaches. The UC tissue was sliced at a thickness of 10-14 $\mu \mathrm{m}$ using a cryostat (CM3050S, Leica Biosystems, Newcastle Upon Tyne, UK). Subsequently, the DP and UC tissues were immediately submerged in Buffer RLT, which is a proprietary component of the RNeasy Fibrous Mini Kit ${ }^{\circledR}$ (Qiagen, Valencia, CA, USA).

2.2. RNA Extraction. We used similar study procedures applied by Song et al. [15], Lee et al. [16], and Kim et al. [17]. Total RNA was extracted from DP and UC tissues using the RNeasy Fibrous Mini Kit (Qiagen) according to the manufacturer's instructions. The extracted RNA was eluted in $25 \mu \mathrm{L}$ of sterile water. Prior to RNA extraction, tissues were homogenized using a Bullet Blender ${ }^{\circledR}$ Bead (Next Advanced, Averill Park, NY, USA). RNA concentrations were determined from absorbance values at a wavelength of $260 \mathrm{~nm}$ using a spectrophotometer (Nanodrop ND-1000 ${ }^{\circledR}$, Thermo Scientific, Waltham, MA, USA). RNA samples used in this study had $260 / 280 \mathrm{~nm}$ ratios equal to or greater than 1.8 .

2.3. cDNA Microarray. Global gene expression analyses were performed using GeneChip ${ }^{\circledR}$ Human Gene 1.0 ST oligonucleotide arrays (Affymetrix, Santa Clara, CA, USA). The average amount of RNA isolated from DP and UC tissues was $1 \mu \mathrm{g}$. Total RNA was isolated using the RNeasy Fibrous Mini Kit columns as described by the manufacturer (Qiagen). RNA quality was assessed using the Agilent 2100 Bioanalyzer with an RNA 6000 Nano Chip ${ }^{\circledR}$ (Agilent Technologies, Amstelveen, Netherlands). RNA quantity was determined using the Nanodrop ND-1000. Each RNA sample was subjected to global gene expression analysis according to the manufacturer's protocol (http://www.affymetrix.com/). Briefly, $300 \mathrm{ng}$ of total RNA from each sample was converted to double-stranded cDNA. Using a random hexamer incorporating a T7 promoter, amplified RNA (cRNA) was generated from the double-stranded cDNA template via an in vitro transcription reaction and was purified using the Affymetrix sample cleanup module. cDNA was generated by random-primer reverse transcription using a dNTP mix containing dUTP. The cDNA was then fragmented using the restriction endonucleases uracil-DNA glycosylase and human apurinic/apyrimidinic endonuclease. Next, the fragmented cDNA was end-labeled via a terminal transferase reaction incorporating a biotinylated dideoxynucleotide. Fragmented end-labeled cDNA was hybridized to the GeneChip Human Gene 1.0 ST array for $16 \mathrm{~h}$ at $45^{\circ} \mathrm{C}$ and $60 \mathrm{rpm}$ as described in the GeneChip Whole Transcript Sense Target Labeling Assay Manual (Affymetrix). After hybridization, the chips were stained and washed in a GeneChip Fluidics Station 450 and scanned using a GeneChip Array scanner 3000 G7 (Affymetrix). The image data were extracted using Command Console software 1.1 (Affymetrix) and a raw file containing the expression intensity data was generated and used for the next step. This microarray data set was approved by the Gene Expression Omnibus (GEO) (https://www.ncbi.nlm.nih.gov/geo/); the GEO accession numbers of the data set are GSE75642 (umbilical cord) and GSE75644 (dental pulp).

2.4. Gene Ontology Analysis. Expression data were generated using Expression Console software version 1.1 (Affymetrix). For normalization, the Robust Multiarray Average algorithm of the Expression Console software was used. In order to determine whether genes were differentially expressed in the three groups, a one-way ANOVA was performed on the Robust Multiarray Average expression values. A multiple testing correction was applied to the $p$ values of the $F$-statistics to adjust the false discovery rate. Genes with adjusted $F$-statistic $p$ values $<0.05$ were extracted. Highly expressed genes that showed over 2 -fold differences between the signal values in 
TABLE 1: Quantitative RT-PCR primer lists.

\begin{tabular}{lccc}
\hline Gene symbol & Gene description & Assay ID & Amplicon length \\
\hline AMBN & Ameloblastin (enamel matrix protein) & Hs00212970_m1 & 61 \\
ALCAM (CD166) & Activated leukocyte cell adhesion molecule & Hs00977641_m1 & Hs00191821_m1 \\
CALB1 & Calbindin 1 & Hs00990732_ml & 90 \\
CD34 & CD34 molecule & Hs01009391_g1 & 91 \\
DMP1 & Dentin matrix acidic phosphoprotein 1 & Hs00171962_m1 & 106 \\
DSPP & Dentin sialophosphoprotein & Hs00174838_m1 & 67 \\
MCAM (CD146) & Melanoma cell adhesion molecule & Hs00153408_m1 & 77 \\
MYC & c-Myc & Hs03003631_gl & 107 \\
18S & 18S rRNA & & 69 \\
\hline
\end{tabular}

the control and each test group were selected for further investigation. In order to classify the coexpression gene group with a similar expression pattern, we performed hierarchical and $K$-mean clustering using MultiExperiment Viewer software 4.4 (http://www.tm4.org/, Dana-Farber Cancer Institute, Boston, MA, USA). The web-based tool, DAVID (the Database for Annotation, Visualization, and Integrated Discovery), was used for biological interpretation of differentially expressed genes. Subsequently, these genes were classified based on their function according to the KEGG Pathway database (https://david.ncifcrf.gov/home.jsp).

\subsection{Quantitative Reverse Transcription Polymerase Chain} Reaction. The single-stranded cDNA required in the PCR analysis step was produced using $500 \mathrm{ng}$ of extracted total RNA as a template for reverse transcription (Superscript III Reverse Transcriptase and Random Primer, Invitrogen, Paisley, UK). The reverse transcription reaction was performed at $65^{\circ} \mathrm{C}$ for 5 minutes, followed by $25^{\circ} \mathrm{C}$ for 5 minutes, $50^{\circ} \mathrm{C}$ for 1 hour, and $70^{\circ} \mathrm{C}$ for 15 minutes to inactivate the reverse transcriptase. The synthesized cDNA was diluted $10: 1$ in distilled water and used as a template for qRTPCR, which was performed using the ABI7300 RT-PCR system (Applied Biosystems, Warrington, UK). Samples of $25 \mu \mathrm{L}$ containing $1 \mathrm{x}$ Universal TaqMan Master Mix (4369016, Applied Biosystems), PCR primers at a concentration of $0.9 \mu \mathrm{M}$, and the diluted cDNA were prepared in triplicate. The amplification conditions were $50^{\circ} \mathrm{C}$ for 2 minutes and $95^{\circ} \mathrm{C}$ for 10 minutes followed by 40 cycles of $95^{\circ} \mathrm{C}$ for 15 seconds and $60^{\circ} \mathrm{C}$ for 1 minute. TaqMan gene expression assay primers (Applied Biosystems) were used. The primers for each gene are listed in Table 1. ABI 7300 SDS 1.3.1 software (Applied Biosystems) was used to record the fluorescence intensity of the reporter and quencher dyes. Fluorescence intensity values were plotted against time and quantified as the cycle number. A precise quantification of the initial target was obtained by examining the amplification plots during the early log phase of product accumulation above background (the threshold cycle (Ct) number). Ct values were subsequently used to determine $\Delta \mathrm{Ct}$ values $(\Delta \mathrm{Ct}=\mathrm{Ct}$ of the gene minus $\mathrm{Ct}$ of the 18S rRNA gene control), and differences in $\mathrm{Ct}$ values were used to quantify the relative amount of PCR product, expressed as the relative change by applying the equation
$2^{-\Delta \mathrm{Ct}}$. The specific primer assay ID and product sizes for each gene are listed in Table 1.

2.6. Immunohistochemical Staining. For IHC staining, tissues from permanent teeth and the UC were fixed in $10 \%$ buffered formalin (Sigma-Aldrich, St. Louis, MO, USA) for 1 day. Permanent teeth were decalcified using 10\% EDTA ( $\mathrm{pH} 7.4$; Thermo Fisher Scientific, Houston, TX, USA) for 8 weeks. The permanent teeth and UC tissues were embedded in paraffin and sectioned at a thickness of $3 \mu \mathrm{m}$. Specimens were subjected to IHC staining with antibodies against DSPP (rabbit polyclonal, diluted 1:1500; sc-33586, Santa Cruz Biotechnology, Santa Cruz, CA, USA), DMP1 (rabbit polyclonal, diluted 1:100; Ab82351, Abcam), CALB1 (rabbit polyclonal, diluted 1:400; Ab25085, Abcam), and CD146 (MCAM, rabbit polyclonal, diluted 1: 400; Ab75769, Abcam). Endogenous peroxidase activity was quenched by the addition of $3 \%$ hydrogen peroxide. Sections were incubated in $5 \%$ bovine serum albumin to block nonspecific binding. The primary antibodies were diluted to obtain optimal staining and sections were incubated overnight. After incubation, the EnVision+ System-HRP Labeled Polymer Anti-Rabbit kit (K4003, Dako, Carpinteria, CA, USA; ready to use) was applied for 20 minutes. Color development was performed using labeled streptavidin biotin kits (Dako) according to the manufacturer's instructions. The sections were counterstained with Gill's hematoxylin (Sigma-Aldrich). Control sections were treated in the same manner but without primary antibodies.

\section{Results}

3.1. Gene Expression Profiles of UC and DP Tissues. Complementary DNA microarray technology was used to compare multiple gene expression profiles representative of DP and UC tissues. In order to investigate these differentially expressed genes further, data with a more stringent threshold of 3-fold differential expression were filtered to ensure biological significance. The results indicated that 1,957 out of 33,297 (5.88\%) genes exhibited an absolute expression change at least 3-fold. The expression levels of 988 genes were 3 -fold higher in the UC than in DP tissues, while the expression levels of 969 genes were at least 3-fold higher in DP than in 


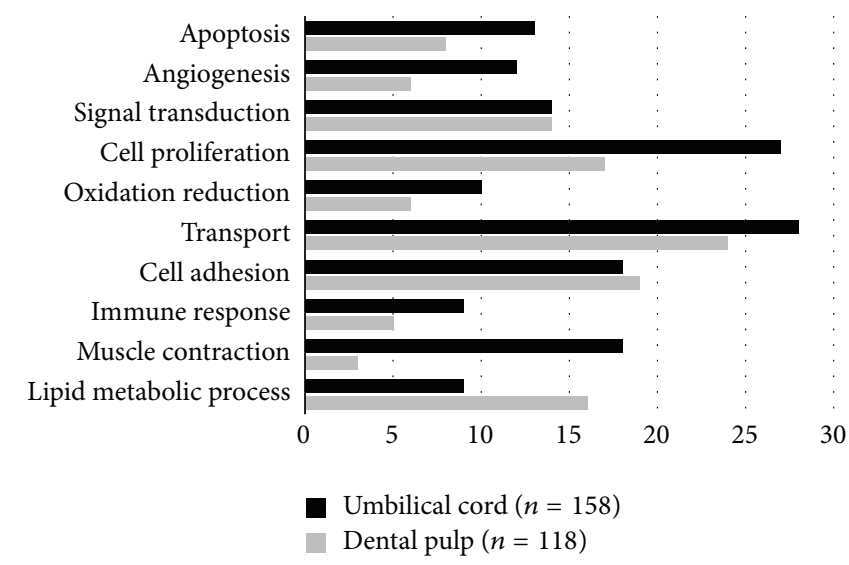

(a)

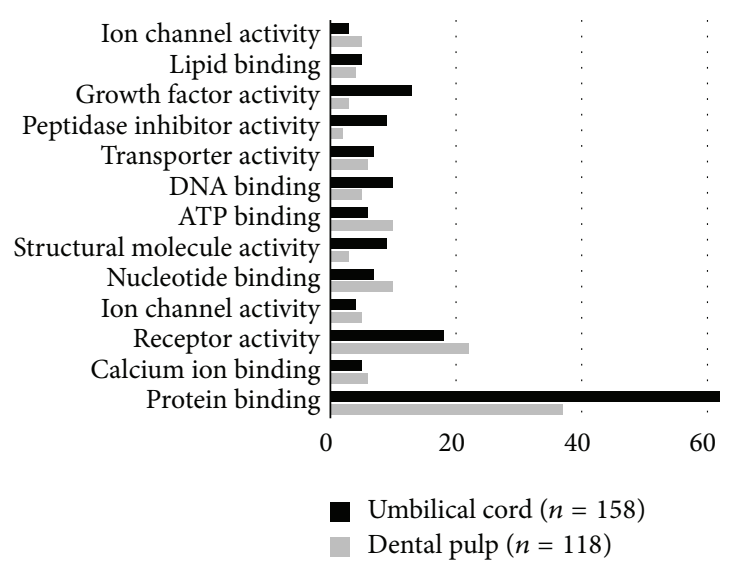

(b)

FIGURE 1: Main categories of genes expressed specifically in umbilical cord and dental pulp classified according to their biological (a) and molecular functions (b). Genes related to cell proliferation and angiogenesis were expressed at higher levels in the UC than in DP $(p<0.05)$.

UC tissues. The data were further filtered, and the genes are listed in Tables 2 and 3 according to their biological functions.

3.2. Gene Ontology Analysis. In the UC tissue, the expression levels of 158 genes were upregulated 10-fold or more in comparison with DP, whereas the expression levels of 118 genes were upregulated 10 -fold in DP in comparison with UC. Genes related to cell proliferation and angiogenesis were expressed at higher levels in UC than in DP. Lipid metabolic process-related genes were highly expressed in DP. In comparison with DP, a large proportion of the UC genes were related to growth factor activity, structural molecular activity, DNA binding, and protein binding (Figure 1).

\subsection{Stemness Characterization Using Surface Protein Markers.}

The comparative expression results for MSC surface protein markers are indicated in Figure 3. UC tissue appeared to contain a population of cells that were more positive for MSC markers (including CD29, CD34, CD44, CD73, CD105, CD146, and CD166) according to the minimal criteria of the International Society for Cell Therapy [18]. The comparative expression analysis of four induced pluripotent stem cell (iPSC) marker genes (i.e., OCT4, SOX2, MYC, and KLF4) revealed that the expression level of these genes was the same in UC and DP. qRT-PCR analysis for eight important marker genes revealed four tooth-related genes (DSPP, $A M B N, C A L B 1$, and $D M P 1)$, three genes for MSCs (CD34, CD146, and CD166), and MYC related to iPSC stemness. DSPP, AMBN, CALB1, and DMP1 were expressed in DP tissue but they were not excluded in the comparative qPCR results because they were not detected in UC tissue. The expression levels of CD146, CD166, and MYC were 18.3, 8.24, and 1.63 times higher, respectively, in UC than in DP, and the expression level of CD34 was 2.15 times higher in DP than in UC (Figure 2).

3.4. Immunohistochemical Staining. MCAM (CD146) was expressed abundantly as a perivascular stem cell marker in connective tissue, especially in the arteries of the UC.
However, this protein showed a very low level of expression in DP tissue (Figure 3). IHC staining showed that DSPP, DMP1, and CALB1 were expressed broadly in DP tissue (Figure 4), but barely expressed in the UC. DSPP was evident in pulpal tissue, the odontoblast layer, and primary and secondary dentin. While DMP was stained in the odontoblast layer and secondary dentin, CALB1 was expressed in pulpal tissue and the odontoblast layer. These findings were consistent with the microarray data.

\section{Discussion}

Although numerous studies have been performed to evaluate the utility of human MSCs as sources for the development of cell-based therapeutics, a precise understanding of the biology of MSCs remains elusive. Previous studies, based on a strict definition of MSCs at the molecular or cellular levels, involved serial analyses of gene expression. However, such approaches raised concerns that the expression of housekeeping genes may have interfered with the identification of MSC-specific genetic characteristics. To overcome such shortcomings, we examined DNA microarray-based differential expression profiles of MSC population, comparing these profiles with those of other tissues to evaluate stemness capacity. We compared DP with UC tissue as both types contain stromal stem cell populations with high proliferative potential that are capable of regenerating their respective microenvironments with remarkable fidelity [19]. In order to identify genes expressed at higher levels in UC than in DP tissue, we categorized genes according to the ratio of the fold change between the two tissues. Results of qRT-PCR and IHC staining analyses confirmed the validity of these data, indicating that the expression of representative genes was consistent with the differential expression patterns observed in the microarray data.

Although MSCs originating from both tissues are highly similar, their differences may be functionally related to their origin; for example, MSCs derived from DP are more committed to the osteoblastic and odontogenic lineages, whereas 
TABLE 2: Representative differentially expressed genes with higher expression levels in umbilical cord than in dental pulp tissue.

\begin{tabular}{|c|c|c|c|c|}
\hline Functional category & $\begin{array}{l}\text { Gene } \\
\text { symbol }\end{array}$ & Biological process & Accession number & $\begin{array}{l}\text { Absolute fold } \\
\text { change }\end{array}$ \\
\hline \multirow{16}{*}{$\begin{array}{l}\text { Embryonic } \\
\text { development }\end{array}$} & DLK1 & $\begin{array}{l}\text { Embryonic skeletal system } \\
\text { development }\end{array}$ & NM_003836 & 56.86 \\
\hline & DKK1 & Embryonic limb morphogenesis & NM_012242 & 44.51 \\
\hline & SCEL & $\begin{array}{l}\text { Epidermis development, embryo } \\
\text { development }\end{array}$ & NM_144777 & 33.26 \\
\hline & TBX18 & $\begin{array}{l}\text { Morphogenesis of embryonic } \\
\text { epithelium }\end{array}$ & NM_001080508 & 15.66 \\
\hline & HOXD10 & $\begin{array}{l}\text { Embryonic skeletal system } \\
\text { morphogenesis }\end{array}$ & NM_002148 & 12.03 \\
\hline & TBX20 & $\begin{array}{l}\text { Embryonic heart tube } \\
\text { development }\end{array}$ & NM_001077653 & 11.71 \\
\hline & $\mathrm{HOXC10}$ & Embryonic limb morphogenesis & NM_017409 & 8.70 \\
\hline & HOXC6 & $\begin{array}{l}\text { Embryonic skeletal system } \\
\text { development }\end{array}$ & NM_004503 & 7.22 \\
\hline & HAND2 & In utero embryonic development & NM_021973 & 6.54 \\
\hline & HOXA6 & $\begin{array}{l}\text { Embryonic skeletal system } \\
\text { morphogenesis }\end{array}$ & NM_024014 & 5.50 \\
\hline & EDN1 & In utero embryonic development & NM_001955 & 5.35 \\
\hline & WNT4 & $\begin{array}{l}\text { Embryonic epithelial tube } \\
\text { formation }\end{array}$ & NM_030761 & 4.31 \\
\hline & GATA6 & In utero embryonic development & NM_005257 & 4.17 \\
\hline & TGFB1I1 & $\begin{array}{l}\text { Morphogenesis of embryonic } \\
\text { epithelium }\end{array}$ & NM_001042454 & 4.13 \\
\hline & TGFB3 & In utero embryonic development & NM_003239 & 3.85 \\
\hline & SOX5 & In utero embryonic development & NM_152989 & 3.70 \\
\hline \multirow{16}{*}{$\begin{array}{l}\text { Developmental } \\
\text { process }\end{array}$} & DES & Cytoskeleton organization & NM_001927 & 66.18 \\
\hline & KRT6A & Ectoderm development & NM_005554 & 27.69 \\
\hline & KRT5 & Epidermis development & NM_000424 & 22.73 \\
\hline & KRT13 & $\begin{array}{l}\text { Epidermis development, tongue } \\
\text { morphogenesis }\end{array}$ & NM_153490 & 22.53 \\
\hline & COL12A1 & $\begin{array}{l}\text { Skeletal system development, } \\
\text { collagen fibril organization }\end{array}$ & NM_004370 & 17.87 \\
\hline & DKK2 & $\begin{array}{l}\text { Multicellular organismal } \\
\text { development }\end{array}$ & NM_014421 & 12.63 \\
\hline & TAGLN & Muscle organ development & NM_001001522 & 11.91 \\
\hline & KRT8 & Cytoskeleton organization & NM_002273 & 11.04 \\
\hline & KRT14 & Epidermis development & NM_000526 & 9.01 \\
\hline & OSTN & $\begin{array}{l}\text { Ossification, multicellular } \\
\text { organismal development }\end{array}$ & NM_198184 & 8.22 \\
\hline & MCAM & $\begin{array}{l}\text { Anatomical structure } \\
\text { morphogenesis }\end{array}$ & NM_006500 & 7.22 \\
\hline & IGF2BP3 & $\begin{array}{l}\text { Anatomical structure } \\
\text { morphogenesis }\end{array}$ & NM_006547 & 7.10 \\
\hline & ADAM19 & $\begin{array}{l}\text { Fertilization, muscle } \\
\text { development, neurogenesis }\end{array}$ & NM_033274 & 6.41 \\
\hline & MGP & $\begin{array}{l}\text { Cartilage condensation, } \\
\text { ossification }\end{array}$ & NM_001190839 & 5.70 \\
\hline & $\mathrm{DMD}$ & $\begin{array}{l}\text { Muscle organ development, } \\
\text { skeletal muscle tissue } \\
\text { development }\end{array}$ & NM_000109 & 5.22 \\
\hline & PITX2 & $\begin{array}{l}\text { Multicellular organismal } \\
\text { development }\end{array}$ & NM_153426 & 4.79 \\
\hline
\end{tabular}


TABLE 2: Continued.

\begin{tabular}{|c|c|c|c|c|}
\hline Functional category & $\begin{array}{l}\text { Gene } \\
\text { symbol }\end{array}$ & Biological process & Accession number & $\begin{array}{l}\text { Absolute fold } \\
\text { change }\end{array}$ \\
\hline \multirow{14}{*}{ Physiological process } & ACTG2 & Muscle contraction & NM_001615 & 115.24 \\
\hline & HBG1 & Transport & NM_000559 & 101.65 \\
\hline & PLN & $\begin{array}{l}\text { Cellular calcium ion } \\
\text { homeostasis, blood circulation }\end{array}$ & NM_002667 & 71.69 \\
\hline & CNN1 & $\begin{array}{l}\text { Regulation of smooth muscle } \\
\text { contraction }\end{array}$ & NM_001299 & 66.37 \\
\hline & $\mathrm{HBB}$ & $\begin{array}{l}\text { Regulation of blood pressure, } \\
\text { oxygen transport }\end{array}$ & NM_000518 & 38.48 \\
\hline & FGF10 & Angiogenesis & NM_004465 & 31.24 \\
\hline & COL8A1 & Angiogenesis & NM_001850 & 12.02 \\
\hline & AHSP & $\begin{array}{l}\text { Hemoglobin metabolic process, } \\
\text { hematopoiesis }\end{array}$ & NM_016633 & 7.18 \\
\hline & FGF9 & $\begin{array}{l}\text { Angiogenesis, osteoblast } \\
\text { differentiation }\end{array}$ & NM_002010 & 5.07 \\
\hline & PDGFA & $\begin{array}{l}\text { Angiogenesis, response to } \\
\text { hypoxia }\end{array}$ & NM_002607 & 5.00 \\
\hline & ELN & $\begin{array}{l}\text { Respiratory gaseous exchange, } \\
\text { blood circulation }\end{array}$ & NM_000501 & 4.75 \\
\hline & EGF & $\begin{array}{l}\text { Angiogenesis, positive regulation } \\
\text { of cell proliferation }\end{array}$ & NM_001963 & 4.30 \\
\hline & IL18 & $\begin{array}{l}\text { Angiogenesis, response to } \\
\text { hypoxia }\end{array}$ & NM_001562 & 3.85 \\
\hline & VEGFA & $\begin{array}{l}\text { Angiogenesis, ovarian follicle } \\
\text { development }\end{array}$ & NM_001025366 & 3.16 \\
\hline \multirow{9}{*}{$\begin{array}{l}\text { Signal transduction } \\
\text { and regulation }\end{array}$} & PRLR & $\begin{array}{l}\text { Cell surface receptor linked } \\
\text { signaling pathway }\end{array}$ & NM_000949 & 90.61 \\
\hline & RASSF3 & Signal transduction & NM_178169 & 12.27 \\
\hline & RERG & $\begin{array}{l}\text { GTPase mediated signal } \\
\text { transduction }\end{array}$ & NM_032918 & 11.98 \\
\hline & STC2 & $\begin{array}{l}\text { Cell surface receptor linked } \\
\text { signaling pathway }\end{array}$ & NM_003714 & 11.37 \\
\hline & CD244 & Signal transduction & NM_016382 & 8.83 \\
\hline & ASPN & $\begin{array}{l}\text { Negative regulation of } \\
\text { transforming growth factor beta } \\
\text { receptor signaling pathway }\end{array}$ & NM_017680 & 8.20 \\
\hline & LPHN3 & $\begin{array}{l}\text { G-protein coupled receptor } \\
\text { protein signaling pathway }\end{array}$ & NM_015236 & 7.72 \\
\hline & SPSB1 & Intracellular signaling pathway & NM_025106 & 6.87 \\
\hline & ALCAM & $\begin{array}{l}\text { Signal transduction, motor axon } \\
\text { guidance }\end{array}$ & NM_001627 & 3.96 \\
\hline \multirow{10}{*}{$\begin{array}{l}\text { Cell regulation and } \\
\text { proliferation }\end{array}$} & UPK1B & Epithelial cell differentiation & NM_006952 & 45.66 \\
\hline & MYOCD & Cardiac cell differentiation & NM_001146312 & 40.32 \\
\hline & EGFL6 & Cell differentiation & NM_015507 & 11.94 \\
\hline & PODN & $\begin{array}{l}\text { Negative regulation of cell } \\
\text { proliferation }\end{array}$ & NM_153703 & 9.96 \\
\hline & FAS & $\begin{array}{l}\text { Positive regulation of necrotic } \\
\text { cell death }\end{array}$ & NM_000043 & 9.34 \\
\hline & KRT4 & $\begin{array}{l}\text { Epithelial cell differentiation, } \\
\text { negative regulation of epithelial } \\
\text { cell proliferation }\end{array}$ & NM_002272 & 6.52 \\
\hline & IGFBP7 & Regulation of cell growth & NM_001553 & 6.01 \\
\hline & HEMGN & $\begin{array}{l}\text { Cell differentiation, regulation of } \\
\text { osteoblast differentiation }\end{array}$ & NM_018437 & 5.70 \\
\hline & $\mathrm{CDH1}$ & $\begin{array}{l}\text { Trophectodermal cell } \\
\text { differentiation }\end{array}$ & NM_004360 & 5.44 \\
\hline & $\mathrm{DPT}$ & $\begin{array}{l}\text { Cell adhesion, negative } \\
\text { regulation of cell proliferation }\end{array}$ & NM_001937 & 5.13 \\
\hline
\end{tabular}


TABLE 2: Continued.

\begin{tabular}{|c|c|c|c|c|}
\hline Functional category & $\begin{array}{l}\text { Gene } \\
\text { symbol }\end{array}$ & Biological process & Accession number & $\begin{array}{l}\text { Absolute fold } \\
\text { change }\end{array}$ \\
\hline \multirow{14}{*}{$\begin{array}{l}\text { Cytokine, chemokine, } \\
\text { and immune response }\end{array}$} & IL1RL1 & Immune response & NM_016232 & 36.22 \\
\hline & S100A8 & $\begin{array}{l}\text { Chemotaxis, inflammatory } \\
\text { response }\end{array}$ & NM_002964 & 26.48 \\
\hline & DPP4 & $\begin{array}{l}\text { Regulation of } \mathrm{T} \text { cell mediated } \\
\text { immunity }\end{array}$ & NM_001935 & 18.16 \\
\hline & ITGB6 & Inflammatory response & NM_000888 & 15.01 \\
\hline & IGF2BP1 & $\begin{array}{l}\text { Regulation of cytokine } \\
\text { biosynthetic process }\end{array}$ & NM_006546 & 9.59 \\
\hline & LY96 & $\begin{array}{l}\text { Inflammatory response, cellular } \\
\text { defense response }\end{array}$ & NM_015364 & 8.40 \\
\hline & CCRL1 & Chemotaxis, immune response & NM_178445 & 7.81 \\
\hline & ANLN & Cytokinesis & NM_018685 & 7.60 \\
\hline & CMKLR1 & Chemotaxis, immune response & NM_001142343 & 7.41 \\
\hline & CD97 & $\begin{array}{l}\text { Inflammatory response, immune } \\
\text { response }\end{array}$ & NM_078481 & 6.96 \\
\hline & CXCL1 & $\begin{array}{l}\text { Chemotaxis, inflammatory } \\
\text { response, immune response }\end{array}$ & NM_001511 & 5.54 \\
\hline & IL33 & $\begin{array}{l}\text { Positive regulation of } \\
\text { macrophage activation }\end{array}$ & NM_033439 & 5.29 \\
\hline & CXCR1 & $\begin{array}{l}\text { Chemotaxis, inflammatory } \\
\text { response }\end{array}$ & NM_000634 & 3.48 \\
\hline & CXCL6 & $\begin{array}{l}\text { Chemotaxis, inflammatory } \\
\text { response }\end{array}$ & NM_002993 & 3.07 \\
\hline
\end{tabular}

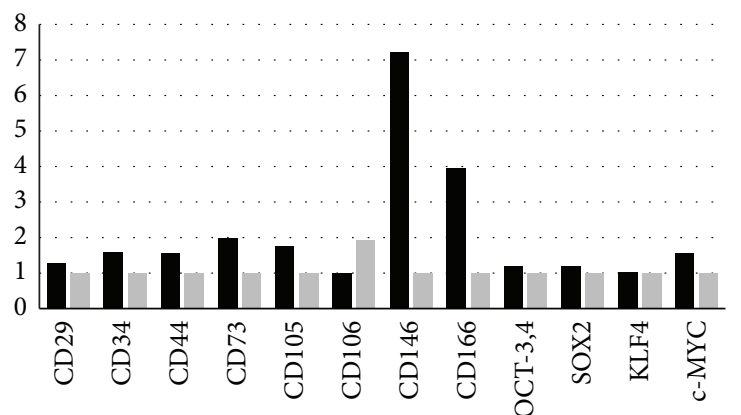

Umbilical cord Dental pulp

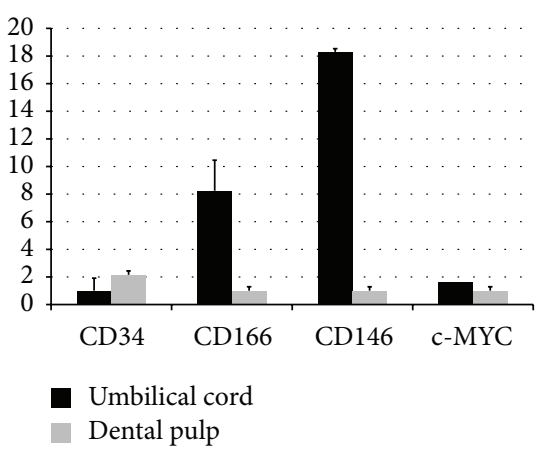

(b)

Figure 2: Relative gene expression of mesenchymal stem cell and induced pluripotent stem cell markers using cDNA microarray (a). The relative differences in the expression of stem cell markers between umbilical cord and dental pulp were analyzed using qRT-PCR (b). Data are presented as means \pm standard deviation and expressed as the relative change by applying the equation $2^{-\Delta \mathrm{Ct}}$, where $\Delta \mathrm{Ct}=\mathrm{Ct}$ of the gene minus Ct of the $18 \mathrm{~S}$ rRNA.

MSCs derived from the UC would be more committed to angiogenesis. In DP tissue, microarray results indicated that certain genes (DMP1, AMBN, DSPP, DLX1, RUNX2, LEF1, $P A X 9$, and MSX1) related to odontogenesis and biomineral tissue development were upregulated, which was in agreement with the expected results for this biological process. In addition, genes that might be related to bone and dentin mineralization, including PHEX, CALB1, MMP20, ALPL, $L H X 8$, and $W N T 10 A$, were upregulated. Microarray data showed that the expression of DMP1, DSPP, and CALB that play important roles in the development of pulp tissue was 99.2, 98.1, and 41.3 times higher, respectively, in DP than in UC. qRT-PCR results indicated that the fold differences in the expression of $D M P 1, C A L B 1$, and $A M B N$ were not observed in the UC. Similarly, IHC staining results showed that DMP1, $C A L B 1$, and DSPP were not stained in the UC but were stained around the outer area of DP. The genetic pattern analysis of permanent pulp indicated that $C A L B 1$, a representative gene in DP, is necessary for enamel mineralization in transitionand maturation-stage ameloblasts [17]. 
TABLE 3: Representative differentially expressed genes with higher expression levels in dental pulp tissue than in umbilical cord.

\begin{tabular}{|c|c|c|c|c|}
\hline Functional category & $\begin{array}{l}\text { Gene } \\
\text { symbol }\end{array}$ & Biological process & $\begin{array}{l}\text { Accession } \\
\text { number }\end{array}$ & $\begin{array}{l}\text { Absolute fold } \\
\text { change }\end{array}$ \\
\hline \multirow{15}{*}{$\begin{array}{l}\text { Biomineral tissue } \\
\text { development }\end{array}$} & PHEX & Bone and dentin mineralization & NM_000444 & 160.01 \\
\hline & DMP1 & Bone and dentin mineralization & NM_004407 & 99.20 \\
\hline & CALB1 & Hydroxyapatite formation & NM_004929 & 98.07 \\
\hline & MMP20 & $\begin{array}{l}\text { Regulation of enamel mineralization, } \\
\text { proteolysis }\end{array}$ & NM_004771 & 85.26 \\
\hline & AMBN & $\begin{array}{l}\text { Bone mineralization, odontogenesis of } \\
\text { dentine-containing tooth }\end{array}$ & NM_016519 & 65.69 \\
\hline & DSPP & Odontogenesis of dentine-containing tooth & NM_014208 & 41.26 \\
\hline & ALPL & Biomineral tissue development & NM_000478 & 14.83 \\
\hline & DLX1 & Odontogenesis of dentine-containing tooth & NM_178120 & 9.55 \\
\hline & LHX8 & Odontogenesis of dentine-containing tooth & NM_001001933 & 7.56 \\
\hline & CA2 & Odontogenesis of dentine-containing tooth & NM_000067 & 7.07 \\
\hline & RUNX2 & Ossification, osteoblast differentiation & NM_001024630 & 6.53 \\
\hline & LEF1 & Odontogenesis of dentine-containing tooth & NM_016269 & 6.24 \\
\hline & PAX9 & Tooth development & NM_006194 & 5.79 \\
\hline & MSX1 & Odontogenesis, craniofacial development & NM_002448 & 4.04 \\
\hline & WNT10A & $\begin{array}{l}\text { Regulation of odontogenesis of } \\
\text { dentine-containing tooth }\end{array}$ & NM_025216 & 3.87 \\
\hline \multirow{16}{*}{$\begin{array}{l}\text { Developmental } \\
\text { process }\end{array}$} & DLX5 & Osteoblast differentiation & NM_005221 & 30.01 \\
\hline & DLX3 & Multicellular organismal development & NM_005220 & 26.13 \\
\hline & ADAM22 & $\begin{array}{l}\text { Proteolysis, central nervous system } \\
\text { development }\end{array}$ & NM_021723 & 25.00 \\
\hline & NES & Central nervous system development & NM_006617 & 15.67 \\
\hline & BMP7 & Ossification, organ morphogenesis & NM_001719 & 15.60 \\
\hline & BMPR1B & $\begin{array}{l}\text { Skeletal system development, cartilage } \\
\text { condensation }\end{array}$ & NM_001203 & 13.53 \\
\hline & MSX2 & $\begin{array}{l}\text { Skeletal system development, osteoblast } \\
\text { differentiation }\end{array}$ & NM_002449 & 9.32 \\
\hline & COL11A2 & $\begin{array}{l}\text { Skeletal system morphogenesis, cartilage } \\
\text { development, palate development }\end{array}$ & NM_001163771 & 8.55 \\
\hline & BMP5 & Skeletal system development, ossification & NM_021073 & 6.08 \\
\hline & TBX3 & $\begin{array}{l}\text { Blood vessel development, in utero } \\
\text { embryonic development }\end{array}$ & NM_016569 & 5.93 \\
\hline & MBP & $\begin{array}{l}\text { Central nervous system development, } \\
\text { myelination }\end{array}$ & NM_001025101 & 4.95 \\
\hline & DLX6 & $\begin{array}{l}\text { Multicellular organismal development, } \\
\text { nervous system development }\end{array}$ & NM_005222 & 4.12 \\
\hline & NRCAM & $\begin{array}{l}\text { Axonogenesis, central nervous system } \\
\text { development }\end{array}$ & NM_001193582 & 4.09 \\
\hline & SNAI1 & $\begin{array}{l}\text { Osteoblast differentiation, mesoderm } \\
\text { formation }\end{array}$ & NM_005985 & 3.78 \\
\hline & HLF & $\begin{array}{l}\text { Multicellular organismal development, } \\
\text { rhythmic process }\end{array}$ & NM_002126 & 3.23 \\
\hline & BMP2 & Development of bone and cartilage & NM_001200 & 2.11 \\
\hline \multirow{7}{*}{ Physiological process } & $\mathrm{TF}$ & $\begin{array}{l}\text { Controlling iron concentrations, } \\
\text { erythropoiesis }\end{array}$ & NM_001063 & 153.98 \\
\hline & SCN7A & Sodium ion transport, muscle contraction & NM_002976 & 82.36 \\
\hline & APOD & Lipid metabolic process & NM_001647 & 41.22 \\
\hline & PLAT & Response to hypoxia, blood coagulation & NM_000930 & 10.20 \\
\hline & CD52 & $\begin{array}{l}\text { Elevation of cytosolic calcium ion } \\
\text { concentration }\end{array}$ & NM_001803 & 4.29 \\
\hline & CYGB & $\begin{array}{l}\text { Response to oxidative stress, oxygen } \\
\text { transport }\end{array}$ & NM_134268 & 3.98 \\
\hline & MYOT & Muscle contraction & NM_006790 & 3.26 \\
\hline
\end{tabular}


TABLE 3: Continued.

\begin{tabular}{|c|c|c|c|c|}
\hline Functional category & $\begin{array}{l}\text { Gene } \\
\text { symbol }\end{array}$ & Biological process & $\begin{array}{l}\text { Accession } \\
\text { number }\end{array}$ & $\begin{array}{c}\text { Absolute fold } \\
\text { change }\end{array}$ \\
\hline \multirow{8}{*}{$\begin{array}{l}\text { Signal transduction } \\
\text { and regulation }\end{array}$} & WIF1 & Wnt receptor signaling pathway & NM_007191 & 70.19 \\
\hline & PTN & $\begin{array}{l}\text { Transmembrane receptor protein signaling } \\
\text { pathway }\end{array}$ & NM_002825 & 38.17 \\
\hline & WNT5A & Oncogenesis, embryogenesis & NM_003392 & 13.68 \\
\hline & NCAM1 & Neurite outgrowth, synaptic plasticity & NM_181351 & 7.87 \\
\hline & NCAM2 & Neurite outgrowth, synaptic plasticity & NM_004540 & 7.38 \\
\hline & RASGRF2 & $\begin{array}{l}\text { Induction of apoptosis by extracellular } \\
\text { signals }\end{array}$ & NM_006909 & 6.88 \\
\hline & CHN1 & Signal transduction & NM_001822 & 6.56 \\
\hline & MET & $\begin{array}{l}\text { Cell surface receptor linked signaling } \\
\text { pathway }\end{array}$ & NM_001127500 & 3.01 \\
\hline \multirow{12}{*}{$\begin{array}{l}\text { Cell regulation and } \\
\text { proliferation }\end{array}$} & SCIN & Negative regulation of cell proliferation & NM_001112706 & 58.65 \\
\hline & RELN & $\begin{array}{l}\text { Cell morphogenesis involved in } \\
\text { differentiation }\end{array}$ & NM_005045 & 49.12 \\
\hline & NES & Structural organization of the cell & NM_006617 & 15.67 \\
\hline & MEGF10 & Phagocytosis & NM_032446 & 9.89 \\
\hline & EPCAM & Positive regulation of cell proliferation & NM_002354 & 8.79 \\
\hline & PDGFD & Positive regulation of cell division & NM_025208 & 5.43 \\
\hline & CLU & $\begin{array}{l}\text { Cell death, positive regulation of cell } \\
\text { proliferation }\end{array}$ & NM_001831 & 5.19 \\
\hline & VEGFC & $\begin{array}{l}\text { Angiogenesis, positive regulation of } \\
\text { neuroblast proliferation }\end{array}$ & NM_005429 & 3.74 \\
\hline & MSI2 & Stem cell development & NM_138962 & 3.55 \\
\hline & $\mathrm{DBC1}$ & Cell cycle arrest, cell death & NM_014618 & 3.32 \\
\hline & TGFB1 & $\begin{array}{l}\text { Cell growth, cell proliferation, cell } \\
\text { differentiation and apoptosis }\end{array}$ & NM_000660 & 3.14 \\
\hline & IGFBP6 & Regulation of cell growth & NM_002178 & 3.07 \\
\hline \multirow{8}{*}{$\begin{array}{l}\text { Cytokine, chemokine, } \\
\text { and immune response }\end{array}$} & IGJ & Immune response & NM_144646 & 22.65 \\
\hline & IGHD & Immune response & BC021276 & 11.30 \\
\hline & CXCL14 & $\begin{array}{l}\text { Chemotaxis, immune response, inhibiting } \\
\text { angiogenesis }\end{array}$ & NM_004887 & 8.74 \\
\hline & SELE & $\begin{array}{l}\text { Leukocyte migration involved in } \\
\text { inflammatory response }\end{array}$ & NM_000450 & 5.82 \\
\hline & MX1 & $\begin{array}{l}\text { Induction of apoptosis, defense response, } \\
\text { response to virus }\end{array}$ & NM_002462 & 5.24 \\
\hline & IFI44 & Response to virus & NM_006417 & 5.05 \\
\hline & CX3CL1 & $\begin{array}{l}\text { Chemotaxis, defense response, immune } \\
\text { response }\end{array}$ & NM_002996 & 3.60 \\
\hline & CFI & Innate immune response & NM_000204 & 3.17 \\
\hline
\end{tabular}

MSCs possess multilineage differentiation potential with a variety of chemokines, cytokines, and growth factors involved in the regeneration of damaged tissue. They are capable of modifying their molecular activities and functions in response to the environment. The exclusive expression of the chemokines CXCL1 and CXCL6 in the UC may increase propagation of hematopoietic precursors in coculture settings. Other genes expressed at higher levels in the UC include those encoding IL-6, IL-18, FGF9, FGF10, PDGFA, EGF, and VEGFA, which are part of interconnected pathways related to angiogenesis. Jin et al. reported that MSCs derived from bone marrow, adipose tissue, and the UC have significantly different anti-inflammatory capacities and confirmed that UC-MSCs exhibit the greatest anti-inflammatory effects
[20]. These findings suggest that UC-MSCs are more efficient for clinical applications involving revascularization.

In this study, the comparison of stemness of UC and DP tissues revealed no significant fold difference in the expression of several surface markers (CD29, CD34, CD44, CD73, CD105, and CD106) typical for MSCs. Nevertheless, some differences were observed in the expression level of CD146 (MCAM) and CD166 (ALCAM), which connect the control of cell growth with cell migration. These findings are representative of the developmental process. The qRT-PCR results showed that the expression levels of CD146 and CD166 were higher in UC than in DP (18.3-fold and 8.24-fold, resp.). These molecular differences in tissue-specific MSC gene expression may reflect their functional activities in distinct 


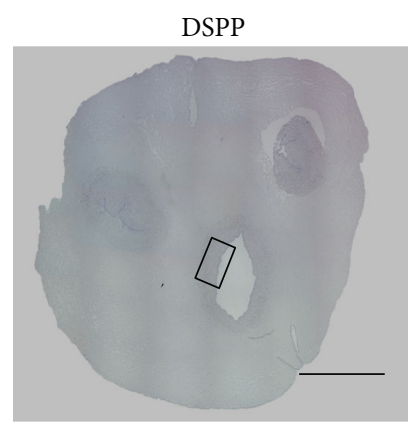

(a)

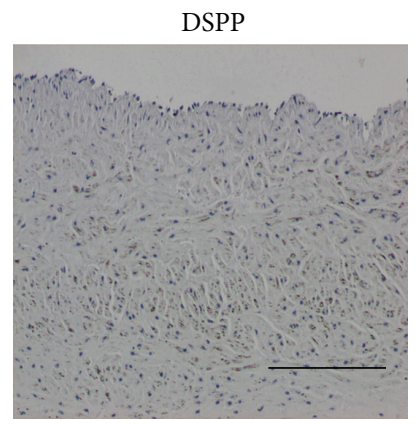

(e)

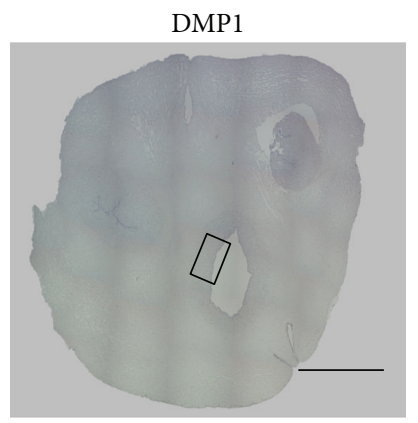

(b)

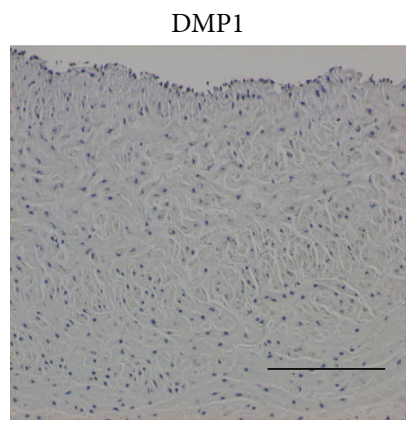

(f)

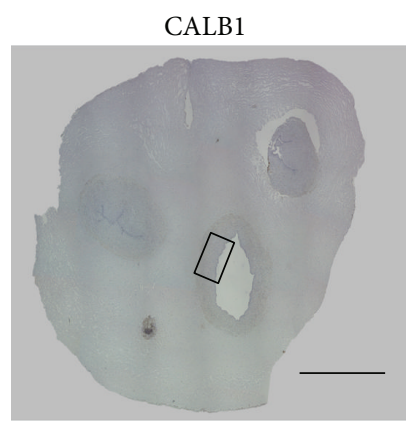

(c)

CALB1

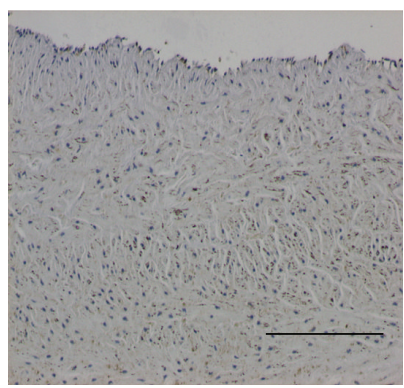

(g)

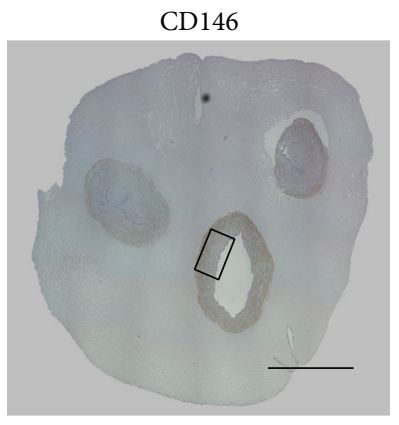

(d)

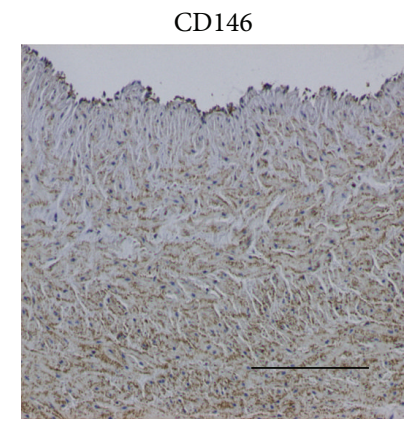

(h)

FIGURE 3: Immunohistochemical (IHC) staining of umbilical cord tissues. IHC staining for DSPP (a, e), DMP1 (b, f), CALB1 (c, g), and CD146 $(\mathrm{d}, \mathrm{h})$. CD146 is expressed on arteries of the umbilical cord, suggesting that the majority of stem cells arise from the microvasculature. (scale bars: (a)-(d) $4 \mathrm{~mm},(\mathrm{e})-(\mathrm{h}) 200 \mu \mathrm{m})$.

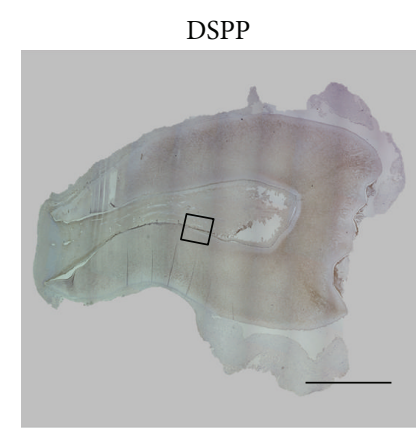

(a)

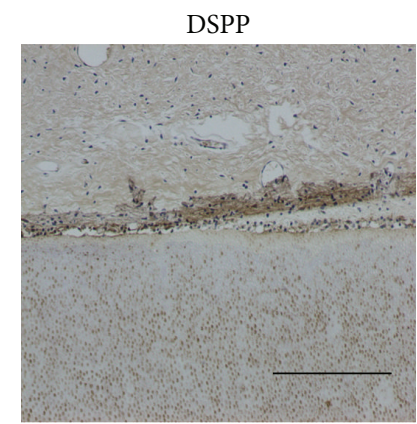

(e)

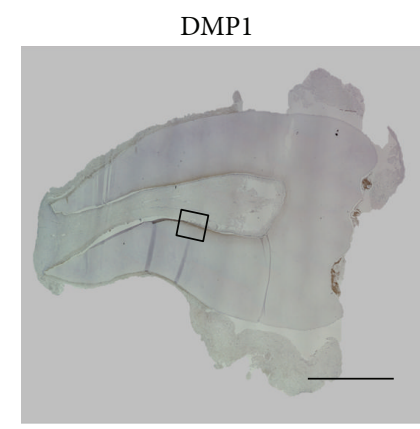

(b)

DMP1

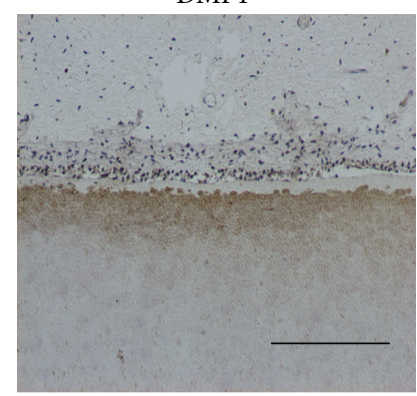

(f)

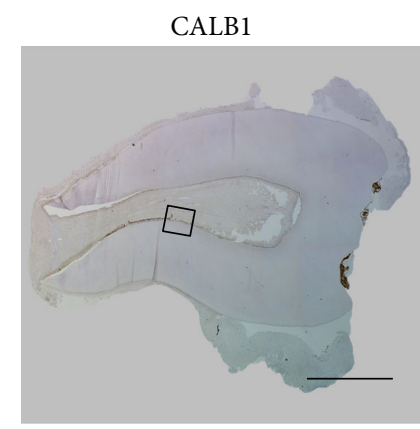

(c)

CALB1

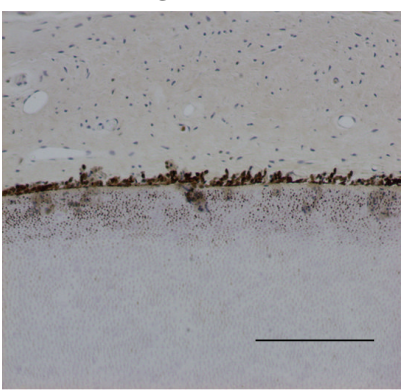

(g)

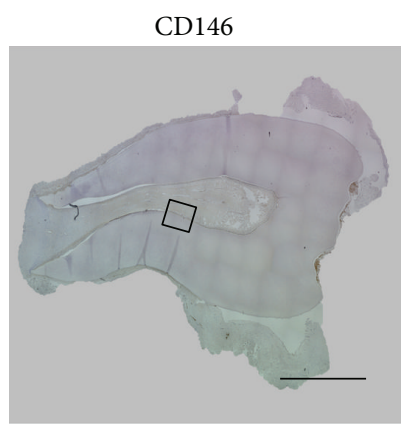

(d)

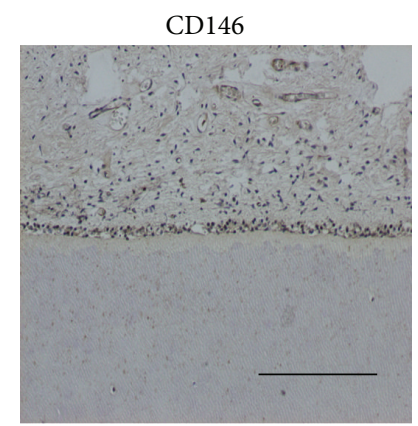

(h)

FIGURE 4: Immunohistochemical (IHC) staining of dental pulp tissue. IHC staining for DSPP (a, e). DSPP was noted in pulpal tissue, the odontoblast layer, and primary and secondary dentin. IHC staining for DMP1 (b, f) and CALB1 (c, g). CALB1 was especially expressed in pulpal tissue and the odontoblast layer. IHC staining for CD146 (d, h) (scale bars: (a)-(d) $4 \mathrm{~mm}$, (e)-(h) $200 \mu \mathrm{m}$ ). 
niches. A study utilizing flow cytometry reported higher expression of CD146, a marker expressed on both BMSCs and DP-MSCs [21]. IHC data confirmed that CD146 is a marker of vascular endothelial cells expressed on arteries of the UC and the outer walls of blood vessels in DP, suggesting that the majority of stem cells arise from the microvasculature. Accumulating evidence suggests that the expression of CD166 reflects the onset of a cellular program involving neural development, branching organ development, hematopoiesis, the immune response, and tumor progression [22]. Struys et al. reported that cultured DPSCs and UC-MSCs showed a similar expression pattern of antigens characteristic of MSCs such as CD105, CD29, CD44, CD146, and STRO-1 [23]. DPSCs are also identified by their positive expression of CD29, CD44, CD73, CD90, CD105, and STRO-1 [19]. CD34 protein is a specific antigen in hematopoietic cells, indicating that a greater number of immature hematopoietic cells are present in both UC and DP [24]. CD34 is present on the outer cell walls of DP and in the connective tissue of the UC, in agreement with previous studies reporting that CD34 localizes on large blood vessels, but not capillaries [25].

The expression of pluripotent stem cell genes in the UC and DP might reflect their embryonic origin. iPSCs are the most promising cell source for cell-based therapy in regenerative medicine, as they give rise to development by introducing 4 factors: MYC, KLF4, OCT4, and SOX2 [7]. No significant differences were found between the expressions of these factors in the two tissue types; MYC, KLF4, OCT4, and SOX2 were expressed 1.57, 1.03, 1.20, and 1.20 times more highly, respectively, in UC than in DP tissue. Previously, DPSCs were characterized by the low levels of expression of undifferentiated cell-associated genes, such as OCT4, MYC, and Nanog, which are considered to facilitate reprogramming [26]. Recent studies utilizing the UC to derive iPSCs are expected to contribute to the further expansion of its pluripotency for therapeutic purposes, including drug discovery [27, 28].

The UC expresses specific embryonic cell markers such as DLK1, DKK1, TBX18, WNT4, and TGFB3. Previous studies describing the expression of embryonic cell markers in the UC have shown that fetal perivascular cells express Runxl and OCT-4 at different levels, which characterizes the undifferentiated stem cell state [29]. Interestingly, UC-MSCs exhibited higher levels of expression of genes related to cell proliferation than DPSCs, whereas DPSCs exhibited a higher proliferation rate compared with BMSCs in vitro [11]. Previous study revealed similar result of this research that UC-MSCs seemed to have higher cell proliferation ability, while DP-MSCs may have significant differences for lower cell apoptosis, osteogenic differentiation, and senescence [30]. This may be attributed to the developmental state of tissues, as UC samples are at an earlier stage of development compared with DP from fully developed and erupted permanent teeth. Commonly expressed genes in DP include those coding for various growth factors (BMP-2, BMP-5, BMP-7, MMP20, and TGF- $\beta 1$ ) implicated as strong promoters of the formation of mineralized bone matrix and tooth morphogenesis [31]. Coexpression of genes with known functions, and unknown or novel genes, may provide a simple means to obtain data about genes for which little information is available.

Although the results of this study are still limited and require further investigation using additional methods, the similarity between MSCs derived from the UC and DP at the transcription level definitively places both tissues as potentially more accessible sources of MSCs. Furthermore, the present gene expression analysis confirms similarities between MSCs derived from the UC and DP and provides molecular and biological insights into the developmental mechanisms involved in angiogenic and odontogenic processes.

\section{Conclusions}

Here, we presented comparative gene expression data for human UC and DP tissue. Although UC tissue showed similar but slightly higher expression patterns, with the usual MSC markers, both tissues clearly diverged in their differentiation capacity. Further research is necessary to understand and describe the significance of these findings for clinical applications.

\section{Disclosure}

The funders had no role in study design, data collection and analysis, decision to publish the paper, or preparation of the paper.

\section{Competing Interests}

The authors declare that there are no competing interests regarding the publication of this paper.

\section{Authors' Contributions}

Chung-Min Kang and Hyunok Kim equally contributed to this work.

\section{Acknowledgments}

This research was supported by the Basic Science Research Program of the National Research Foundation of Korea (NRF) funded by the Ministry of Education, Science and Technology (2011-0022160 and 2012R1A1A2041910). The authors would like to thank Professor Kim Y-H and Cho H-Y of the Department of Obstetrics and Gynecology, Severance Hospital, Yonsei University, for tissue collection and Jeon M. for data analysis.

\section{References}

[1] M. F. Pittenger, A. M. Mackay, S. C. Beck et al., "Multilineage potential of adult human mesenchymal stem cells," Science, vol. 284, no. 5411, pp. 143-147, 1999.

[2] W. A. Silva Jr., D. T. Covas, R. A. Panepucci et al., "The profile of gene expression of human marrow mesenchymal stem cells," Stem Cells, vol. 21, no. 6, pp. 661-669, 2003. 
[3] M. L. Weiss and D. L. Troyer, "Stem cells in the umbilical cord," Stem Cell Reviews, vol. 2, no. 2, pp. 155-162, 2006.

[4] C. K. Rebelatto, A. M. Aguiar, M. P. Moretão et al., "Dissimilar differentiation of mesenchymal stem cells from bone marrow, umbilical cord blood, and adipose tissue," Experimental Biology and Medicine, vol. 233, no. 7, pp. 901-913, 2008.

[5] Y. Chen, Y. Yu, L. Chen et al., "Human umbilical cord mesenchymal stem cells: a new therapeutic option for tooth regeneration," Stem Cells International, vol. 2015, Article ID 549432, 11 pages, 2015.

[6] J. Bosch, A. P. Houben, T. F. Radke et al., "Distinct differentiation potential of ' $\mathrm{mSC}$ ' derived from cord blood and umbilical cord: are cord-derived cells true mesenchymal stromal cells?" Stem Cells and Development, vol. 21, no. 11, pp. 1977-1988, 2012.

[7] K. Takahashi and S. Yamanaka, "Induction of pluripotent stem cells from mouse embryonic and adult fibroblast cultures by defined factor," Cell, vol. 126, no. 4, pp. 663-676, 2006.

[8] X. Wei, G. Peng, S. Zheng, and X. Wu, "Differentiation of umbilical cord mesenchymal stem cells into steroidogenic cells in comparison to bone marrow mesenchymal stem cells," Cell Proliferation, vol. 45, no. 2, pp. 101-110, 2012.

[9] R. A. Panepucci, J. L. C. Siufi, W. A. Silva Jr. et al., "Comparison of gene expression of umbilical cord vein and bone marrowderived mesenchymal stem cells," Stem Cells, vol. 22, no. 7, pp. 1263-1278, 2004.

[10] M. Miura, S. Gronthos, M. Zhao et al., "SHED: stem cells from human exfoliated deciduous teeth," Proceedings of the National Academy of Sciences of the United States of America, vol. 100, no. 10, pp. 5807-5812, 2003.

[11] S. Gronthos, M. Mankani, J. Brahim, P. G. Robey, and S. Shi, "Postnatal human dental pulp stem cells (DPSCs) in vitro and in vivo," Proceedings of the National Academy of Sciences of the United States of America, vol. 97, no. 25, pp. 13625-13630, 2000.

[12] K. Bieback, S. Kern, H. Klüter, and H. Eichler, "Critical parameters for the isolation of mesenchymal stem cells from umbilical cord blood," Stem Cells, vol. 22, no. 4, pp. 625-634, 2004.

[13] R. Karamzadeh, M. B. Eslaminejad, and R. Aflatoonian, "Isolation, characterization and comparative differentiation of human dental pulp stem cells derived from permanent teeth by using two different methods," Journal of Visualized Experiments, 2012.

[14] P. Bianco and P. G. Robey, "Stem cells in tissue engineering," Nature, vol. 414, no. 6859, pp. 118-121, 2001.

[15] J. S. Song, D. H. Hwang, S.-O. Kim et al., "Comparative gene expression analysis of the human periodontal ligament in deciduous and permanent teeth," PLoS ONE, vol. 8, no. 4, Article ID e61231, 2013.

[16] H.-S. Lee, J. Lee, S.-O. Kim et al., “Comparative gene-expression analysis of the dental follicle and periodontal ligament in humans," PLoS ONE, vol. 8, no. 12, Article ID e84201, 2013.

[17] J.-H. Kim, M. Jeon, J.-S. Song et al., "Distinctive genetic activity pattern of the human dental pulp between deciduous and permanent teeth," PLoS ONE, vol. 9, no. 7, Article ID e102893, 2014.

[18] M. Dominici, K. Le Blanc, I. Mueller et al., "Minimal criteria for defining multipotent mesenchymal stromal cells. The International Society for Cellular Therapy position statement," Cytotherapy, vol. 8, no. 4, pp. 315-317, 2006.

[19] S. Shi and S. Gronthos, "Perivascular niche of postnatal mesenchymal stem cells in human bone marrow and dental pulp," Journal of Bone and Mineral Research, vol. 18, no. 4, pp. 696-704, 2003.
[20] H. J. Jin, Y. K. Bae, M. Kim et al., "Comparative analysis of human mesenchymal stem cells from bone marrow, adipose tissue, and umbilical cord blood as sources of cell therapy," International Journal of Molecular Sciences, vol. 14, no. 9, pp. 17986-18001, 2013.

[21] D. Baksh, R. Yao, and R. S. Tuan, "Comparison of proliferative and multilineage differentiation potential of human mesenchymal stem cells derived from umbilical cord and bone marrow," STEM CELLS, vol. 25, no. 6, pp. 1384-1392, 2007.

[22] G. W. M. Swart, "Activated leukocyte cell adhesion molecule (CD166/ALCAM): developmental and mechanistic aspects of cell clustering and cell migration," European Journal of Cell Biology, vol. 81, no. 6, pp. 313-321, 2002.

[23] T. Struys, M. Moreels, W. Martens, R. Donders, E. Wolfs, and I. Lambrichts, "Ultrastructural and immunocytochemical analysis of multilineage differentiated human dental pulp-and umbilical cord-derived mesenchymal stem cells," Cells Tissues Organs, vol. 193, no. 6, pp. 366-378, 2011.

[24] T. Ueda, M. Yoshida, H. Yoshino et al., "Hematopoietic capability of $\mathrm{CD} 34^{+}$cord blood cells: a comparison with $\mathrm{CD} 34^{+}$adult bone marrow cells," International Journal of Hematology, vol. 73, no. 4, pp. 457-462, 2001.

[25] M. Secco, E. Zucconi, N. M. Vieira et al., "Multipotent stem cells from umbilical cord: cord is richer than blood!," STEM CELLS, vol. 26, no. 1, pp. 146-150, 2008.

[26] I. Kerkis, A. Kerkis, D. Dozortsev et al., "Isolation and characterization of a population of immature dental pulp stem cells expressing OCT- 4 and other embryonic stem cell markers," Cells Tissues Organs, vol. 184, no. 3-4, pp. 105-116, 2007.

[27] A. Giorgetti, N. Montserrat, T. Aasen et al., "Generation of induced pluripotent stem cells from human cord blood using OCT4 and SOX2," Cell Stem Cell, vol. 5, no. 4, pp. 353-357, 2009.

[28] A. Haase, R. Olmer, K. Schwanke et al., "Generation of induced pluripotent stem cells from human cord blood," Cell Stem Cell, vol. 5, no. 4, pp. 434-441, 2009.

[29] T. Montemurro, G. Andriolo, E. Montelatici et al., "Differentiation and migration properties of human foetal umbilical cord perivascular cells: potential for lung repair," Journal of Cellular and Molecular Medicine, vol. 15, no. 4, pp. 796-808, 2011.

[30] H. Ren, Y. Sang, F. Zhang, Z. Liu, N. Qi, and Y. Chen, "Comparative analysis of human mesenchymal stem cells from umbilical cord, dental pulp, and menstrual blood as sources for cell therapy," Stem Cells International, vol. 2016, Article ID 3516574, 13 pages, 2016.

[31] S. Shi, P. G. Robey, and S. Gronthos, "Comparison of human dental pulp and bone marrow stromal stem cells by cDNA microarray analysis," Bone, vol. 29, no. 6, pp. 532-539, 2001. 

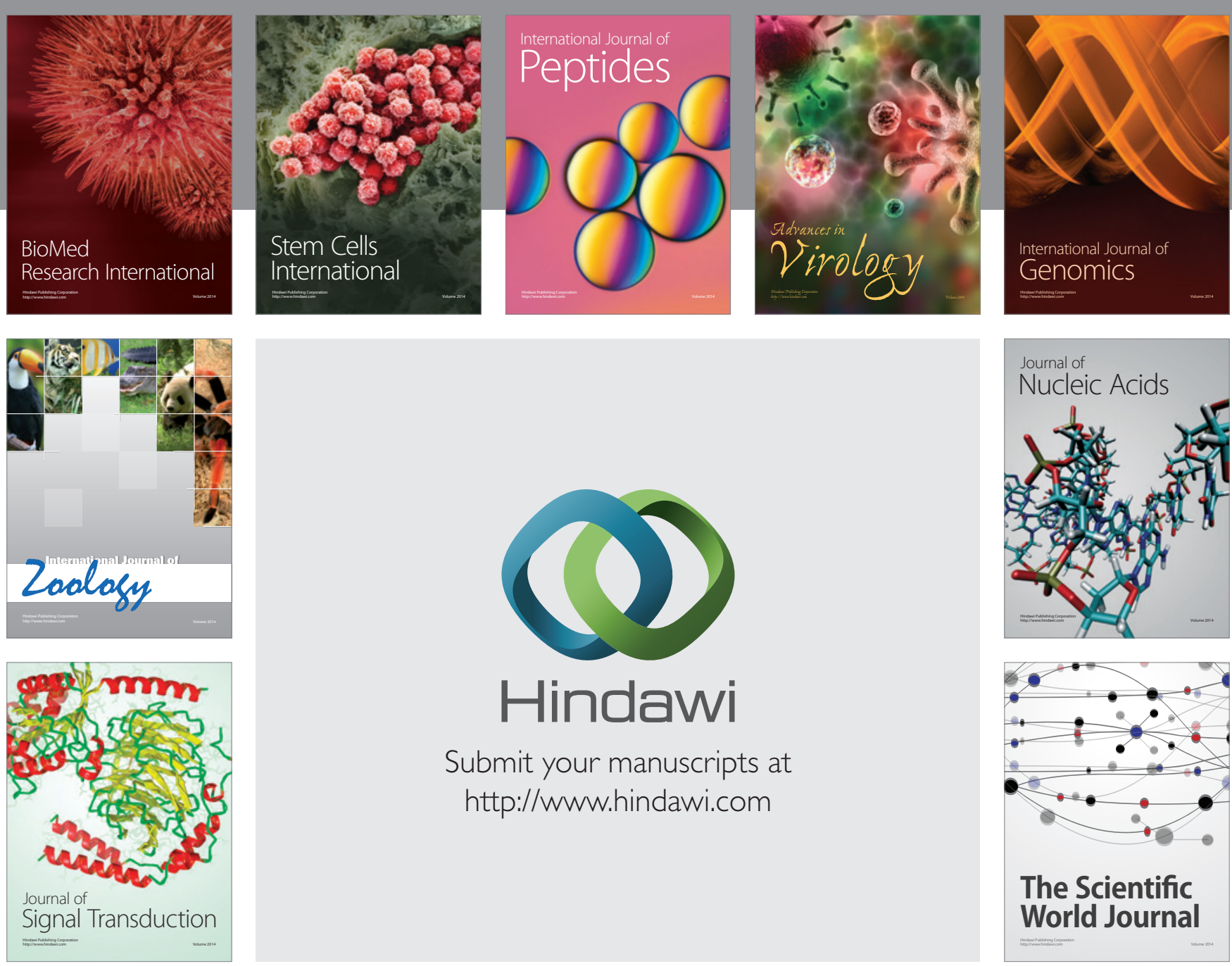

Submit your manuscripts at

http://www.hindawi.com
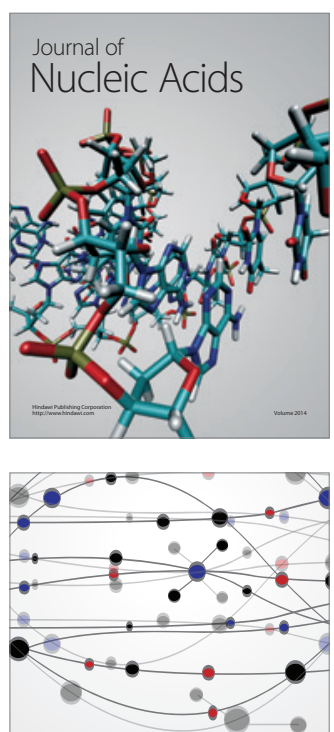

The Scientific World Journal
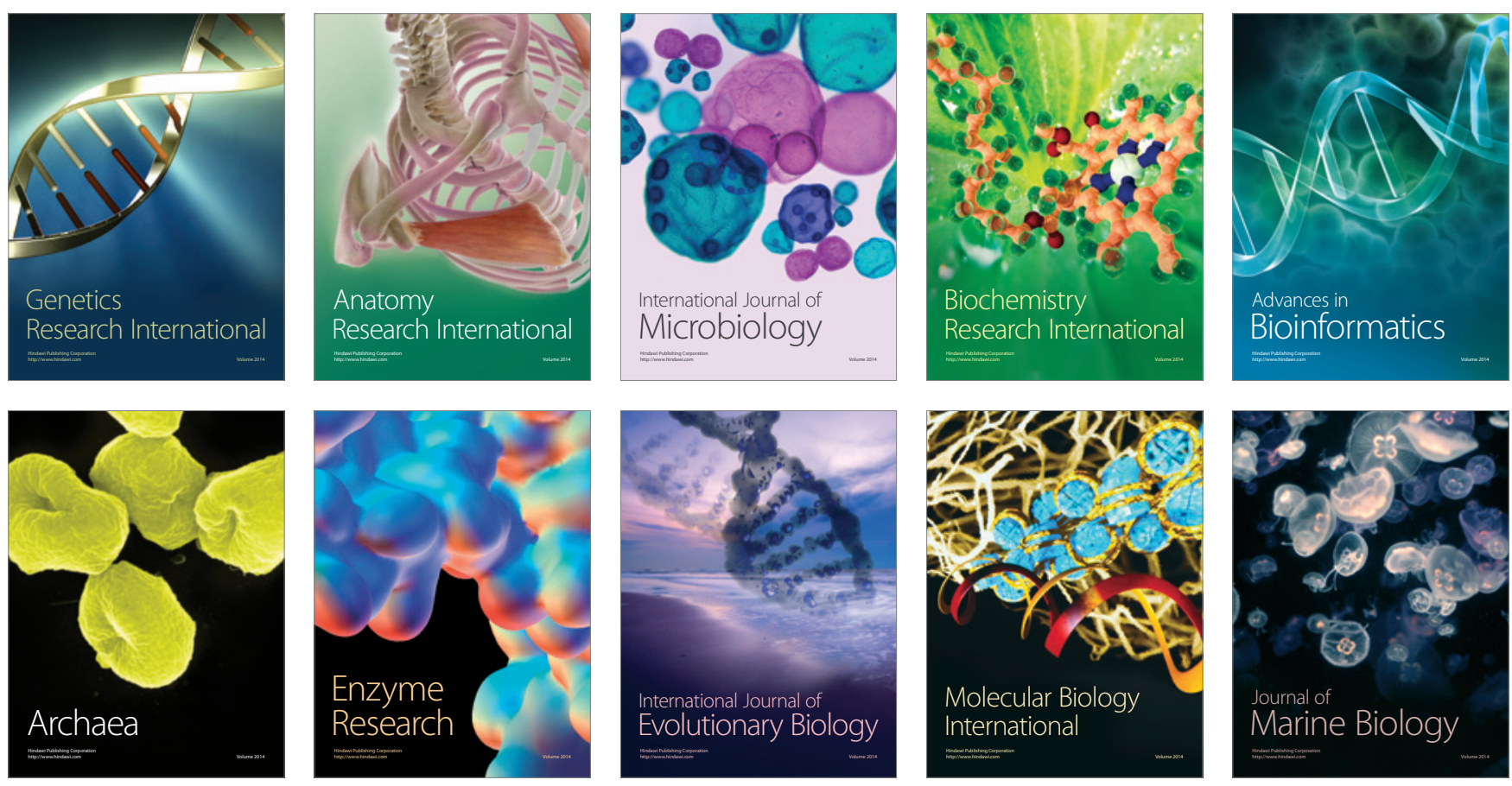